\title{
Can Cybersemiotics solve the problem of informational transdisciplinarity?
}

Søren Brier, Dept. of Management, Society and Communication, Copenhagen Business School, sbr.msc@cbs.dk,26-06-2017.

\begin{abstract}
A transdisciplinary theory for cognition and communication has at least been described from the following paradigms 1 . An objective information processing view or info-mechanicism; 2 . A social constructivist view ; 3 . A systemic cybernetic view of self-organization; 4 . Semiotic paradigms of experience and interpretation (phenomenological and hermeneutical aspects) including biosemiotic going into animal, plant, bacterial and cellular living systems. They all have their transdisciplinary shortcomings. A transdisciplinary framework called Cybersemiotics that integrate phenomenological and hermeneutical aspect in Peircean semiotic logic with cybernetic and systemic autopoietic emergentist process-informational view, is suggested
\end{abstract}

Keywords: Transdisciplinary models, Cybersemiotics, info-computationalism,

\section{Introduction}

Thus we have various attempts of transdisciplinary descriptions of cognition and communication in a material world: 1 . Info-mechanical processing with matter-energy and objective information as basic stuff of the world to which all cognition and communication is to be reduced. It is usually a realistic paradigm [1,2]. This view leaves out the conscious observer as the cause of experiences that can detect differences and make some differences more important than others. Communication is seen as the transfer of objective measured bits information, 2. Constructivisms are based in experiential human beings co-constructing meaning and reality models, but giving up realism for relativism. Thus paradigm 1 and 2 are not compatible. 3 . A general system and cybernetic view with emergence theory attempts to solve this problem through a theory of systems being more than the sums of their parts and the possibility of mergence. But still we know no theory of quality emergence from matter, energy and information to experience (6). But Luhmann's autopoietic second order cybernetic and systems theory [3] makes the individuality of systems a function of their self-limiting through internal negative feedback systems. This creates a sort of agency making objective information transfer alone impossible without structural couplings. But even structural couplings are not interpretations as there is no experiential cognition theoretically established in the theory. It is simply not possible in cybernetics, be it Bateson, Maturana or Luhmann [6]. A Peircean semiotic view [4] starts on a phenomenological ground for meaningfully interpreted cognition and communication combined with pure qualitative mathematics and through pragmaticism has a theory of determining the meaning of a concept or a model [5]. In systems and semiotics Information has to be part of a meaningful message whose information contends are determined by the difference in knowledge between sender and receiver/interpreter. Semiotics is missing a systems and cybernetic theory of the dynamism of self-organizing of embodied systems.

\section{Transdisciplinary paradigms}

Cybersemiotics attempts to combine a systemic and a semiotic view trying to amend the shortcoming of the above described transdisciplinary models into a model that is not totalitarian mechanistic, algorithmic or physicalistic reductionism and on the other hands is not a constructivist relativism giving up any scientific truth claims. Cybernetics and systems 
science attempts to overcome these problems through its dynamics theory of emergence, where like in dialectical materialism now qualities arise in systems development or when to types of systems are integrated. But what if we accepted the social constructivism as a pragmatic fact like in the hypothetical methods? We personally and socially create theories about the world and then accept a fallibilist realism like Popper and Peirce's philosophies of science. Thus in meaningful embodied semiotic and linguistic interaction we create culture as hypothesis of the how the world is structure $\mathrm{d}$ and how its processes function. I suggest that in our embodied cognition and communication we cultivate knowledge in four

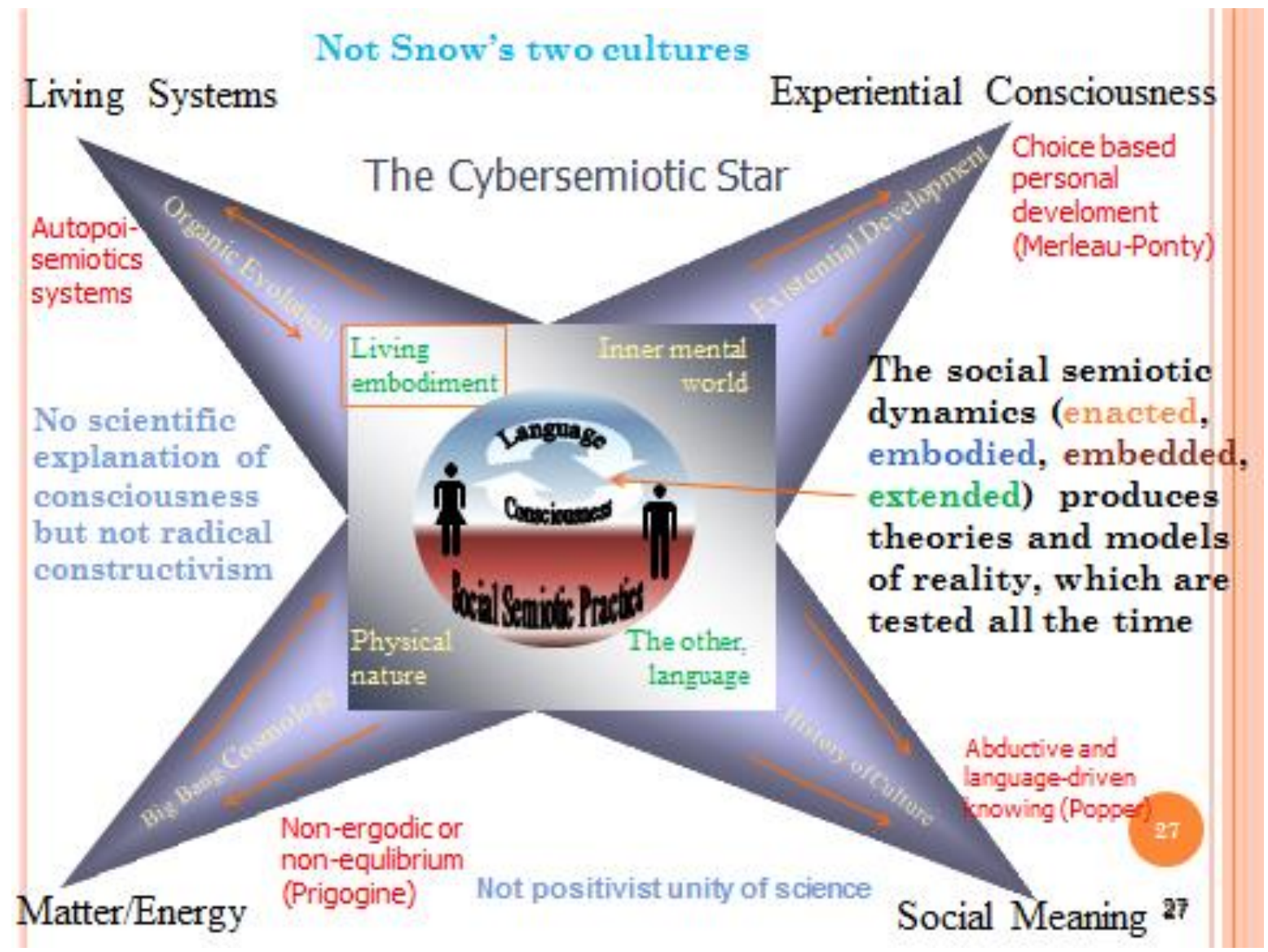

Figure 1. Figure 1: The cybersemiotic Star [7].

main different areas. About the outer world often called nature, but distinguished in a dead and a living part. Our view of the living part takes departure in our own experienced body and empathy with other embodied beings and their ability to have bodily experience of pleasure and pain. The third our is our experiences and mental imaginations meaningful storytelling and phantasies, which led into the four area of communication and culture where a lot of these stories are created and conserved and sometimes even lived out i Cybersemiotic suggest a semiotic pragmaticist theory departing form the social communication from which we create science in itself as the given. A graphical representation is created in figure 1 , where abductively gained explanation flows from the center towards the 
arms of the star out towards the surroundings where our theories can be falsified by that which is as it is no matter what we think about it, as Popper and Peirce suggests in their philosophy of science. But as such it also gives op the belief in final verification of any general scientific knowing. The model does not believe in any simple reductionist explanations be they from physics, biology, phenomenology or social constructivism (any of the spikes of the star). It is a process philosophy of irreversible time in nature, life, mind and culture and as such also considers the habits of nature (often called the laws) as manifesting as the universe develops $[4,9,10]$.

\section{References}

1. Dodig-Crnkovic, G. (2013).The info-computational nature of morphological computing, Philosophy and Theory of Artificial Intelligence, 59-68.

2. Chaitin, G. (2006). Epistemology as information theory, Collapse 1, pp. 27-51.

3. Luhmann, N. (1995): Social Systems. Stanford, CA: Stanford University Press.

4. Peirce, C.S. (1931-58): Collected Papers vol. I-VIII. (eds.) Hartshorne and Weiss. Cambridge MA: Harvard U. P.

5. Kauffman, S. (2012). From physics to semiotics, in Silver Rattasepp, S and Bennett, T. (2012) Gatherings in Biosemiotics, Tartu: Tartu U. P.

6. Kim, J. (1998). Mind in a Physical World: An Essay on the Mind-Body Problem and Mental Causation, Cambridge, Massachusetts: The MIT Press.

7. Brier, S. (2008). Cybersemiotics: Why information is not enough. Toronto U.P.

8. Brier, S. (2015). Finding an information concept suited for a universal theory of information, Progress in Biophysics \& Molecular Biology, 119(3), pp. 622-633.

9. Smolin, L. (2014). Time Reborn: London: Allan Lane.

10. Wheeler, J. A. (1994). At home in the universe, New York: Am. Institute of Physics. 